\title{
Information seeking behavior of women in Kenya to protect themselves from sexual gender-based violence
}

\author{
Caroline Muthoni \\ Åbo Akademi University \\ cmuthoni@abo.fi \\ https://orcid.org/0000-0002-4942-9639
}

Keywords: information seeking behavior, SGBV, women, Kenya

Studies on women's information behavior in Kenya have been conducted in diverse social contexts, as well as in different disciplines (Ngimwa, Ocholla and Ojiambo, 1997; Muthoni and Miller, 2010; Odini, 2014). However, the role that information behavior can play in regard to addressing the problem of sexual gender based violence (SGBV), has not been studied.

SGBV has been reported and acknowledged by the Ministry of health, legislators and researchers as alarmingly prevalent against women in Kenya (Aura, 2014; McEvoy, 2014). This was the background for this author's unpublished 
Master's thesis in Information and Knowledge Management at Åbo Akademi University, upon which this presentation is based (Muthoni, 2019).

In this study, information seeking behavior is understood as the purposive search for information as a result of a perceived need to satisfy some goal. In the course of seeking the individual may interact with manual information systems, computer based systems or alternatively seek information from other people (Wilson, 2000). At the root of information seeking behavior is the concept of information need. The nature of need is subjective in that it is a cognitive representation of a future goal that is desired (Burnkrant, 1976). Needs may emerge from different motives that may be cognitive, affective or physiological (Wilson, 1981). Individuals do not seek information in a vacuum, but are influenced by many factors related to their situation when the information need occurs, i.e. their social, psychological, economic, physical and work environments (Johnson, 2007).

Sexual gender-based violence entails widespread human rights violations and is a complex issue, often linked to unequal power relations between genders and abuses of power. In its various forms, violence against women is one of the most widespread and socially tolerated forms of human rights violations in every culture and country, cutting right across borders, race, class, ethnicity, and religion. (Aura, 2014). The umbrella term gender-based violence (GBV) refers to any harmful act, perpetrated against a person's will or directed against individuals or groups of people on the basis of socially assigned differences between males and females (i.e. gender). It is one of the most severe traumas a human can experience. This trauma does not end when the act of violence is over, survivors of these types of trauma are vulnerable to future acts of traumatization (Kelley, 2015). SGBV includes acts that inflict physical, mental or sexual harm or suffering, threats to such acts, coercions and other deprivations of liberty whether occurring in private or public life, e.g. sexual violence, domestic violence, trafficking. (Aura, 2014; Committee, 2015)

This study uses Wilson's second 1981 (Wilson, 1999) model of information seeking behavior to understand information behavior from an information seeking perspective. The model considers information seeking behavior from within the situated context of the individual who seeks information. Which implies that it considers factors that motivate an individual's information seeking behavior. It therefore provides a theoretical framework that would describe general information seeking behavior applicable in this study. 


\section{Methods and material}

A qualitative approach seemed most appropriate for the study as data analysis and research strategy put more emphasis on words than quantifications. Interpretations of the respondents (attitudes, opinions, behavior) were considered important. The study was interested in how the women interpreted their social world, i.e. the meaning they ascribed to their lived experiences, as a person in an environment/user in context (Wilson, 1981; Wilson, 2000; Niedźwiedzka, 2003; Kothari, 2004; Ikoja-Odongo and Mostert, 2006).

The study comprised a standardized self-completion questionnaire administered online to a sample of Kenyan women, selected through a snowball sampling approach. The sampled group was drawn comprised of students, professionals, single and married. The design and use of an online questionnaire was based on the geographical distance between the researcher and the target population sample, the relative ease of reaching them, and low costs as no interviewer was required. The respondents were assured maintained confidentiality and anonymity (Rudestam and Newton, 2014, given the sensitive nature of the research topic (Fulu et al., 2013). Data from respondents would be saved directly onto a database and therefore easier to analyze (Rudestam and Newton, 2014).

The study questionnaire was developed and refined through feedback. It was subdivided into five sections each with its own theme. The questionnaire comprised mixed questions, i.e. open-response, open and closed-ended. The online version of the questionnaire was hosted on a webpage designed and maintained by the author's university. It was administered to potential respondents through a link attached to an email introducing the research. Which respondents were instructed to click to complete the survey questionnaire online. Data was analyzed using Microsoft Excel pivot tables. This was considered both appropriate for analyzing the results in themes and convenient to use.

\section{Findings}

The findings concurred with previous research on information seeking behavior and showed that to protect themselves from SGBV women sought information through formal and informal sources of information, e.g. health professionals, family, and friends. Manual information systems, e.g. newspapers and libraries, as well as computer based systems e.g. the Internet. The most preferred sources, the internet, smartphone and books, were chosen for 
their convenience, privacy and anonymity. The study recommends that these platforms and resources should be specifically targeted for interventions and response to SGBV in Kenya by collaborating multisector stakeholders, to provide relevant information, services and support. The analysis does not reveal any clear patterns concerning the relationships between e.g. preferred information sources and the respondents' age or personal SGBV experience(s). This might be an important angle for future research to pay attention as it might yield deeper insight and inform collaborating multisector service providers in designing optimum informational interventions.

\section{Acknowledgements}

I wish to thank Professor Gunilla Widén and Dr. Kristina Eriksson-Backa for their guidance, encouragement and support.

\section{References}

Aura, R. (2014). Situational analysis and the legal framework on sexual and gender-based violence in Kenya: Challenges and opportunities. Kenya Law, http://kenyalaw.org/kl/index. php.

Burnkrant, R. E. (1976). A motivational model of information processing intensity. Journal of Consumer Research, 3(1), 21-30. https://doi.org/10.1086/208647

Committee, I.-A. S. (2015). Guidelines for Integrating Gender-Based. Violence Interventions in Humanitarian Action: Reducing risk, promoting resilience and aiding recovery. Inter-Agency Standing Committee. Available at: https://interagencystandingcommittee.org/ working-group/documents-public/iasc-guidelines-integrating-gender-based-violence-interventions.

Fonck, K., et al. (2005). Increased risk of HIV in women experiencing physical partner violence in Nairobi, Kenya. AIDS and Behavior, 9(3), 335-339. https://doi.org/10.1007/s10461-0059007-0

Fulu, E., et al. (2013). Toolkit for Replicating the UN Multi-country Study on Men and Violence: Understanding Why Some Men Use Violence against Women and How We Can Prevent It. Bangkok: UNDP.

Ikoja-Odongo, R., \& Mostert, J. (2006). Information seeking behavior: a conceptual framework. South African Journal of Libraries and Information Science, 72(3), 145-158. https://doi. org $/ 10.7553 / 72-3-1112$

Johnson, C. A. (2007). Social capital and the search for information: Examining the role of social capital in information seeking behavior in Mongolia. Journal of the American Society for Information Science and Technology, 58(6), 883-894. https://doi.org/10.1002/asi.20561 
Kelley, E. (2015). Bringing survivor discourse into the dominant discourse. John Carroll University. Available at: https://collected.jcu.edu/mastersessays/13/.

Kilonzo, N., et al. (2009). Sexual violence legislation in sub-Saharan Africa: the need for strengthened medico-legal linkages. Reproductive Health Matters, 17(34), 10-19. https://doi. org/10.1016/s0968-8080(09)34485-7

Kithaka, A. N. (2008). Enforcement of the Sexual Offences Act in Kenya. Pambazuka Organisation.

Kothari, C. R. (2004). Research methodology: Methods and techniques (2nd ed.). New Delhi: New Age International Publishers.

Makau, A. J., \& Thuo, L. (2013). State Responsibility for Elimination Violence against Women: The Due Diligence Principle and the Role of Judges. Kenya Law.

McEvoy, C. (2014). Challenging impunity: the struggle to tackle gender-based violence in Kenya. Available at: https://www.peaceinsight.org/blog/2014/12/challenging-impunity-struggle-end-gender-based-violence-kenya/.

Muthoni, A., \& Miller, A. N. (2010). An exploration of rural and urban Kenyan women's knowledge and attitudes regarding breast cancer and breast cancer early detection measures. Health Care for Women International, 31(9), 801-816. https: //doi.org/10.1080/07399331003628453

Muthoni, C. (2019). Information Seeking Behaviour of Women In Kenya To Protect Themselves From Sexual Gender-Based Violence. Unpublished master's thesis in Information and Knowledge Management at Åbo Akademi University.

Ngimwa, P., Ocholla, D. N., \& Ojiambo, J. (1997). Media accessibility and utilization by Kenyan rural women. The International Information \& Library Review, 29(1), 45-66. https://doi. org/10.1080/10572317.1997.10762413

Niedźwiedzka, B. (2003). A proposed general model of information behavior. Information research, 9(1), 1-9. Available at: http://www. informationr.net/ir/9-1/paper164.html.

Odini, S. (2014). Access to and use of agricultural information by small scale women farmers in support of efforts to attain food security in Vihiga County, Kenya. Journal of Emerging Trends in Economics and Management Sciences, 5(2), 80-86. https://hdl.handle.net/10520/ EJC152937

Rudestam, K. E., \& Newton, R. R. (2014). Surviving your dissertation: A comprehensive guide to content and process. Thousand Oaks, California: Sage Publications.

Wilson, T. D. (1981). On user studies and information needs. Journal of Documentation, 37(1), 3-15. https://doi.org/10.1108/eb026702

Wilson, T. D. (1999). Models in information behavior research. Journal of documentation, 55(3), 249-270. https://doi.org/10.1108/EUM0000000007145

Wilson, T. D. (2000). Human Information Behavior. Informing Science: The International Journal of an Emerging Transdiscipline, 3(2), 049-056. https://doi.org/10.28945/576 